\title{
MEMBANGUN KETAHANAN INFORMASI DI DAERAH-DAERAH PERBATASAN INDONESIA
}

\author{
Irdayanti \\ Universitas Islam Negeri Sultan Syarif Kasim Riau \\ yanti_kor@yahoo.com
}

\begin{abstract}
Abstrak
Tulisan ini bertujuan untuk menjelaskan permasalahan yang timbul dari minimnya akses informasi yang diperoleh masyarakat daerah perbatasan di Indonesia dengan upaya yang dilakukan pemerintah untuk menjaga ketahanan nasional. Pentingnya akses informasi amat diperlukan untuk mengetahui perkembangan negara sendiri dan menjaga rasa nasionalisme serta membuka akses komunikasi dan informasi, karena dapat menunjang pemasaran komoditas unggulan daerah tersebut. Upaya yang dilakukan pemerintah dalam memecahkan permasalahan ini belum dapat dikatakan maksimal karena dalam proses pengembangan. Namun, i'tikad tersebut dapat terlihat dari pengembangan infrastruktur media informasi, memberikan kemudahan perizinan serta pembelajaran/media literasi kepada masyarakat di daerah-daerah perbatasan.
\end{abstract}

Kata Kunci: Membangun, Ketahanan Informasi, dan Daerah Perbatasan. 


\section{Pendahuluan}

Indonesia merupakan negara kepulauan yang mencapai 17.400 lebih pulau dan dua pertiga dari wilayah Indonesia adalah laut. Implikasinya, hanya ada tiga perbatasan darat dan sisanya adalah perbatasan laut. Perbatasan laut Indonesia berbatasan dengan 10 negara yaitu Malaysia, Singapura, Filipina, India, Thailand, Vietnam, Republik Palau, Australia, Timor Leste, dan Papua Nugini. Sedangkan untuk wilayah darat, Indonesia berbatasan langsung dengan tiga negara, yakni Malaysia, Papua Nugini, dan Timor Leste dengan panjang garis perbatasan darat secara keseluruhan adalah 2914,1 km. Luasnya wilayah perbatasan laut dan darat Indonesia tentunya membutuhkan dukungan sistem manajemen perbatasan yang terorganisir dan profesional, baik di tingkat pusat maupun daerah. Akan tetapi, minimnya infrastruktur di kawasan perbatasan telah menunjukkan bahwa pemerintah tidak memiliki sebuah sistem manajemen perbatasan yang baik.
Kondisi ini dapat dilihat pada perbatasan daerah di pulau Sumatra dan Kalimantan, khususnya di Provinsi Riau terdapat beberapa kabupaten yang langsung berbatasan dengan Malaysia dan hanya dibatasi oleh selat. Empat kabupaten itu adalah Bengkalis, Rokan Hilir, Kepulauan Meranti, dan Dumai. Chanel-chanel TV Malaysia hampir setiap hari bisa ditonton masyarakat. Salah satunya di Desa Selat Baru, Kecamatan Bantan. Beberapa warung dan tempat makan hampir rata-rata memutar channel stasiun televisi Malaysia, TV 1, TV2 dan TV3. Tidak hanya siaran TV, siaran radio pun juga sering didengar dengan bahasa Malaysia (http://harianriau.co/news/detail/14978 /informasi-beberapa-daerah-di-riauberkiblat-ke-malaysia diakses pada tanggal 15 September 2017). Namun, informasi dari negara sendiri sangat minim sekali dan terkadang tidak ada.

$$
\text { Begitu juga masalah }
$$
ketimpangan pembangunan, hampir semua kawasan perbatasan Indonesia adalah daerah tertinggal yang kondisinya sangat memprihatinkan 
sebagai wajah luar negara. Selama ini kawasan perbatasan dikelola dengan mengedepankan pendekatan keamanan (safety belt approach) sehingga pembangunan sosial ekonomi menjadi terabaikan （www.kemitraan.com Partnership Policy Paper No.2/2011). Dalam kajian daerah perbatasan tidak hanya menyangkut aspek pertahanan keamanan atau aspek ekonomi saja. Hal lain yang harus dipertimbangkan adalah kenyataan bahwa kajian masyarakat perbatasan adalah kajian yang tidak bisa lepas dari pengaruh berbagai faktor. Intinya, kendatipun faktor hubungan perdagangan lintas batas itu penting untuk dijadikan penggerak utama bagi kehidupan masyarakat perbatasan (Zainuddin Djafar, 2008: 106), namun kebutuhan informasi juga harus terpenuhi. Jika dilihat lebih jauh daerah perbatasan memiliki permasalahan, yang secara umum meliputi:

1. Belum adanya kepastian dan ketegasan garis batas, baik garis batas laut maupun garis batas darat, serta administrasi dan pemeliharaannya. Akibatnya perencanaan pembangunan wilayah perbatasan menjadi terkendala. Adanya permasalahan batas negara ini banyak menimbulkan dampak negatif dan berbagai insiden di perbatasan dan pelanggaran wilayah kedaulatan.

2. Kondisi masyarakat di kawasan perbatasan pada umumnya masih miskin, tertinggal, terbelakang, tingkat pendidikan dan kesehatan rendah, serta secara komunitas terisolir.

3. Lemahnya penegakan hukum, menyebabkan maraknya pelanggaran hukum di kawasan perbatasan.

4. Belum sinkronnya pengelolaan kawasan perbatasan, baik menyangkut kelembagaan, program, maupun kejelasan wewenang.

5. Adanya kegiatan penyelundupan barang dan Tenaga Kerja Indonesia (TKI).

6. Rentannya persoalan yang terkait dengan nasionalisme penduduk karena kurangnya informasi yang masuk dari Indonesia, dan 
masyarakat di kawasan (Zainuddin Djafar, 2008: 106).

\section{Kedekatan geografis} mempermudah penerimaan informasi dari negara tetangga, namun ketimpangan informasi dari negara sendiri menimbulkan permasalahan tambahan bagi daerah-daerah di perbatasan negara. Banyak potensi daerah yang seharusnya dapat berkembang dan dipasarkan, namun terhambat karena minimnya akses informasi. Seperti penelitian mengenai kemungkinan dihasilkannya alkohol medik dan gasohol dari nira, hasil tumbuhan lontar, yang dilakukan oleh Joko Sulistyo. Bila hal ini ditangani secara serius, pemasukan negara akan bertambah. Menurut Endang Sukara, kalau nira diolah secara serius, produk ini bisa dipakai untuk menutupi semua kebutuhan alkohol medik yang dibutuhkan negeri ini. Penelitian yang mampu mendukung percepatan daerah tertinggal juga tampak pada penelitian Nasrullah Army. Media radio padahal amat diperlukan untuk membuka akses komunikasi dan informasi, karena dapat menunjang pemasaran komoditas unggulan daerah tersebut (http://lipi.go.id/berita/teknologiminim-di-daerah-perbatasan/1224 diakses pada tanggal 16 September 2017).

Selain keterbatasan pengetahuan masyarakat perbatasan terhadap perkembangan informasi dalam negeri, hal ini juga akan berpotensi terhadap munculnya disintegrasi hingga yang paling disesalkan terjadinya pergantian kewarganegaraan. Sehingga yang perlu dilakukan adalah sebuah ketahanan informasi untuk mewujudkan ketahanan nasional Republik Indonesia.

Penelitian ini menggunakan metode kualitatif dengan pendekatan deskriptif. Penelitian deskriptif berusaha menggambarkan suatu gejala sosial. Menurut Burhan Bungin (2007: 68), penelitian sosial menggunakan format deskriptif kualitatif bertujuan untuk menggambarkan, meringkaskan berbagai kondisi, situasi, atau fenomena realitas sosial yang ada di masyarakat yang menjadi objek penelitian, dan berupaya menarik 
realitas itu ke permukaan sebagai suatu ciri, karakter, sifat, model, tanda, atau gambaran tentang kondisi, situasi, ataupun fenomena tertentu. Dengan demikian, penelitian ini akan menjelaskan gambaran realitas dari masalah yang akan peneliti elaborasi dengan menggunakan data-data yang ada

Teknik pengumpulan data dalam penelitian ini menggunakan studi literatur dengan mengumpulkan datadata dan dokumen dari berbagai referensi yang akan dijadikan rujukan.

\section{Pembahasan}

Terbentuknya negara Indonesia dilatarbelakangi oleh perjuangan seluruh rakyat Indonesia sejak lama yang menjadi incaran banyak negara karena potensinya yang besar dilihat dari wilayahnya yang luas dengan kekayaan alam yang banyak. Tujuan nasional bangsa menjadi pokok pikiran bagi perlunya ketahanan nasional karena negara Indonesia sebagai suatu organisasi yang dalam rangka kegiatannya untuk mencapai tujuan akan selalu menghadapi masalah, baik yang berasal dari dalam maupun luar. Oleh karena itu, negara yang mempunyai tujuan nasionalnya sendiri dan mencapai tujuan memerlukan kondisi dinamis yang mampu memberikan fasilitas bagi tercapainya tujuan.

Konsepsi ketahanan nasional adalah konsep pengembangan kekuatan nasional melalui pengaturan dan penyelenggaraan kesejahteraan dan keamanan yang seimbang, serasi, selaras, dan seluruh aspek kehidupan negara serta menyeluruh terpadu berlandaskan falsafah bangsa, Pancasila, UUD 1945, dan wawasan nusantara (Darmadi Hamid, 2013: 107). Dalam mewujudkan ketahanan nasional memiliki asas, yaitu asas komprehensif integral/menyeluruh terpadu. Artinya, ketahanan nasional mencakup seluruh aspek kehidupan, aspek-aspek tersebut berkaitan dalam bentuk persatuan dan perpaduan secara selaras, serasi, dan seimbang. Selama ini fokus perhatian untuk daerah perbatasan terdapat pada aspek pertahanan dan keamanan di mana banyak sekali ditempatkan polisi dan 
tentara untuk menjaga keamanan. Namun, kebutuhan lain yang juga sangat dibutuhkan untuk mencapai ketahanan nasional adalah akses informasi yang minim.

Keadaan ini secara langsung ataupun tidak langsung dapat membahayakan integritas, identitas, serta kelangsungan hidup bangsa dan negara. Seiring dengan perkembangan lingkungan strategis yang sangat cepat dan dinamis, hakikat, jenis, dan bentuk ancaman terhadap kedaulatan NKRI juga terus berubah dan semakin sulit untuk diprediksi secara pasti. Salah satu yang sangat jelas terlihat dan dirasakan dalam kehidupan sehari-hari saat ini ialah ancaman perang informasi yang semakin dahsyat atau keadaan sebaliknya, mimimnya informasi terhadap perkembangan bangsa dan negara. Dua keadaan ini telah membawa dampak yang luar biasa dalam berbagai aspek kehidupan bermasyarakat, berbangsa, dan bernegara.

\section{Ketahanan Informasi Akan Mewujudkan Ketahanan Nasional}

Pada umumnya daerah-daerah perbatasan di Indonesia merupakan daerah tertinggal dengan sarana dan prasarana sosial, politik, ekonomi yang sangat terbatas. Minimnya sarana prasarana tersebut bukan karena keadaan geografisnya yang jauh dari ibu kota atau karena kondisi tanah, namun permasalahan terletak pada pelembagaan ekonomi dan politik yang diciptakan. Selain itu, pandangan di masa lalu bahwa daerah perbatasan merupakan wilayah yang perlu diawasi secara ketat karena merupakan daerah yang rawan keamanan telah menjadikan paradigma pembangunan perbatasan lebih mengutamakan pendekatan keamanan daripada kesejahteraan. Hal ini menyebabkan wilayah perbatasan di beberapa daerah tidak tersentuh oleh dinamika pembangunan.

$$
\text { Pembangunan wilayah }
$$

perbatasan memiliki keterkaitan yang sangat erat dengan misi pembangunan nasional, terutama untuk menjamin 
keutuhan dan kedaulatan wilayah, pertahanan keamanan nasional, serta meningkatkan kesejahteraan rakyat. Pandangan pembangunan selama ini mengarah pada "inward looking” yang harus diubah menjadi "outward looking" yang menjadikan daerah perbatasan menggunakan pendekatan kesejahteraan dengan tidak meninggalkan pendekatan keamanan.

Jika dilihat dari permasalahan yang mucul di daerah perbatasan dengan mudahnya akses informasi kepada negara tetangga dan mimimnya informasi terhadap bangsa sendiri tentu akan melemahkan ketahanan nasional itu sendiri. Seperti yang terjadi pada daerah perbatasan di Riau yang berbatasan dengan Malaysia, yakni Bengkalis, Rokan Hilir (Rohil), Kepulauan Meranti, dan Dumai di mana daerah tersebut hanya dipisahkan oleh selat. Sehingga kedekatan wilayah dan kesamaan budaya membuat masyarakat di perbatasan tersebut begitu mudah menerima segala informasi dari Malaysia, baik televisi maupun radio. Sementara informasi tentang Negara Kesatuan Republik
Indonesia (NKRI) begitu minim. Sudah 72 tahun Indonesia merdeka kondisi itu tetap belum berubah (http://harianriau.co/news/detail/14978 /informasi-beberapa-daerah-di-riauberkiblat-ke-malaysia terbit tanggal 18 Agustus 2017 diakses pada tanggal 15 September 2017).

$$
\text { Dampak dari minimnya }
$$
penyiaran dari lembaga penyiaran lokal maupun nasional telah banyak terbukti, yakni sebagian masyarakat di beberapa wilayah yang berbatasan dengan negara tetangga lebih mengenal lagu kebangsaan negara tersebut ketimbang Indonesia Raya. Itu terjadi karena mereka hampir setiap hari dan sepanjang tahun hanya mendapatkan informasi dari negeri seberang. Dan keadaan yang lebih ekstrim adalah akibat kesenjangan infrastruktur dan fasilitas umum di daerah perbatasan Indonesia-Malaysia, sejak tahun 1977 sekitar 2.000 warga Kabupaten Senggau dan Kabupaten Bengkayang yang bertempat tinggal di daerah perbatasan Kalimantan BaratSerawak memilih berpindah wilayah dan berganti kewarganegaraan menjadi 
warga negara Malaysia

(http://www.dpd.go.id/artikel-wni-jadiwn-malaysia-karena-kesenjangan-

infrastruktur-di-perbatasan diterbitkan tanggal 8 Juni 2010, diakses pada tanggal 15 September 2017).

Oleh sebab itu, tidaklah berlebihan jika ketahanan informasi daerah perbatasan mengalami darurat informasi yang berpotensi terhadap melemahnya ketahanan nasional. Ketahanan informasi perlu dibangun agar timbul kesadaran informasi di tengah masyarakat dan kewaspadaan terhadap ancaman yang akan datang, serta mampu memanfaatkan perkembagan informasi untuk mendukung kehidupan bermasyarakat dan bernegara. Di sinilah pentingnya ketahanan informasi bagi daerahdaerah perbatasan tersebut.

Dalam sebuah bangunan ketahanan informasi, masyarakat harus mampu memilah dan memilih berita yang positif dan negatif serta bijak dalam menyikapinya agar tidak menimbulkan bahaya bagi kehidupan pribadi, bermasyarakat, berbangsa, dan bernegara. Mengacu pada pengertian ketahanan nasional, yaitu sebuah kondisi dinamis suatu bangsa yang berisi keuletan dan ketangguhan yang mampu mengembangkan ketahanan, kekuatan nasional dalam menghadapi dan mengatasi segala tantangan, hambatan dan ancaman, baik yang datang dari dalam maupun dari luar. Juga secara langsung ataupun tidak langsung yang dapat membahayakan integritas, identitas serta kelangsungan hidup bangsa dan negara. Ketahanan nasional diperlukan dalam rangka menjamin eksistensi bangsa dan negara dari segala gangguan, baik yang datang dari dalam maupun luar negeri. Untuk itu bangsa Indonesia harus tetap memiliki keuletan dan ketangguhan yang perlu dibina secara konsisten dan berkelanjutan.

Ketahanan nasional melingkupi seluruh aspek kehidupan berbangsa dan bernegara, tidak hanya politik, sosial, budaya, dan ekonomi. Di era globalisasi saat ini di mana perkembangan teknologi dan informasi yang semakin canggih, juga dibutuhkan sebuah ketahanan, maka ketahanan informasi ini dapat 
dimaknai sebagai sebuah keuletan dan ketangguhan bangsa Indonesia, baik secara infrastruktur, suprastruktur, maupun karakter masyarakat dalam mengelola dan menyikapi perkembangan teknologi informasi agar tidak membahayakan integritas, identitas, serta kelangsungan hidup bangsa dan negara. Ketiga aspek tersebut perlu dibangun secara kuat agar mampu menjadi salah satu komponen ketahanan nasional baru yang bisa mendukung tegak kukuhnya NKRI (https://tniad.mil.id/2017/01/ membangun-ketahanan-informasimenegakkan-ketahanan-nasional/ diterbitkan tanggal 13 Januari 2017 diakses pada tanggal 15 Sepetember 2017).

Pada dasarnya penggunaan teknologi dan media informasi ditujukan untuk kepentingan hidup berbangsa dan bernegara. Seperti yang diamanatkan dalam UUD 1945 pasal 31 Ayat 5 bahwa Pemerintah memajukan ilmu pengetahuan dan teknologi dengan menjunjung tinggi nilai agama dan persatuan bangsa untuk kemajuan peradaban kesejahteraan umat manusia. Dan seharusnya pula penggunaan teknologi dan informasi dirasakan oleh seluruh rakyat Indonesia, tidak terkecuali daerah perbatasan. Merupakan suatu kemustahilan membentuk ketahanan nasional jika masih terjadi kesenjangan informasi di antara rakyat Indonesia. Oleh karena itu, untuk mempertahankan identitas dan jati diri sebagai bangsa yang merdeka dan berdaulat secara utuh, dibutuhkan kesamaan pola pikir, pola sikap, dan pola tindak para penentu kebijakan, stakeholder dan pelaku kegiatan dalam bidang teknologi informasi, yang didasarkan pada konsepsi geopolitik (Wawasan Nusantara) dan geostrategi Indonesia (Ketahanan Nasional).

\section{Pengembangan Infrastruktur dan Kemudahan Perizinan}

$$
\text { Belum adanya kesiapan }
$$

infrastruktur penyiaran di berbagai daerah perbatasan mengakibatkan hak informasi masyarakat di perbatasan masih terabaikan. Untuk itu, Komisi Penyiaran Indonesia (KPI) Pusat 
mendorong Kementerian Komunikasi dan Informatika (Kominfo) untuk segera membangun infrastruktur penyiaran di daerah perbatasan. Selain persoalan teknis, problem penyiaran di daerah perbatasan lainnya adalah persoalan infrastruktur penyiaran yang masih sangat miskin. Jika tidak diselesaikan dengan cepat, maka integrasi nasional bisa terancam. Mengingat banyaknya frekuensi perbatasan yang sudah dikuasai oleh lembaga penyiaran negara tetangga, masyarakat di daerah perbatasan seperti Provinsi Kalimantan Utara masih belum terpenuhi hak-hak informasinya. Perlu diketahui bahwa negara tetangga seperti Malaysia sangat mendominasi informasi di daerah perbatasan. Ini tentu akan sangat mengancam hak informasi masyarakat

Seperti dilansir dari dari riau.com (http://www.daririau.com/read9008790--kpid-mahal-menyaksikansiaran-di-wilayah-perbatasan.html diterbitkan tanggal 17 Desember 2013 diakses pada tanggal 15 September 2017), Ketua Komisi Penyiaran
Indonesia Daerah (KPID) Riau, Zainul Ikhwan menjelaskan bahwa menyaksikan televisi dan mendengarkan radio di wilayah perbatasan Kepulauan Meranti merupakan barang langka dan mahal harganya. Kapasitas energi listrik yang terbatas menyebabkan lembaga penyiaran di daerah perbatasan hanya mampu bersiaran selama 4-6 jam. Kelemahan lainnya adalah dari sisi kualitas, rata-rata radio Malaysia jauh lebih berkualitas dari sisi penerimaan siaran. Sebab kekuatan power radio yang dimiliki negara Malaysia jauh lebih besar dari power radio Indonesia.

Dalam pemenuhan kebutuhan informasi masyarakat di daerah perbatasan ini, sebuah lembaga penyiaran memerlukan dana operasional yang cukup besar, karena biaya operasional di perbatasan itu mahal, misalnya di daerah Kalimantan, Papua, yang semua memakai pesawat terbang. Jadi jika dengan memakai satuan pembiayaan ala pemerintah, tidak mampu diwujudkan dalam waktu yang cepat. Sehingga kemudahan perizinan dan dukungan dari 
pemerintah daerah sangat diperlukan memingat masyarakat perbatasan yang selama ini masih minim merasakan siaran informasi dari dalam negeri, bisa segera menikmati kebutuhan informasi negeri sendiri. Seperti juga dilansir dari kanalsatu.com (http://kanalsatu.com/id/post/1578/pen dirian-lembaga-penyiaran-diperbatasan-dipermudah diterbitkan tanggal, 2 April 2013, diakses pada tanggal 13 September 2017), Menteri Komunikasi dan Informatika, Tifatul Sembiring menegaskan, pemerintah dan Komisi Penyiaran Indonesia (KPI) telah membuat kesepakatan untuk mempermudah pemberian izin bagi pendirian lembaga penyiaran di daerah perbatasan negara.

Kebijakan tersebut diharapkan dapat menarik minat lembaga penyiaran untuk memancarkan siarannya hingga daerah perbatasan dengan negara lain. Selain itu, pemerintah telah membangun pos lintas batas negara (PLBN) di wilayah perbatasan Indonesia dengan negara lain, pemerintah juga membangun infrastruktur telekomunikasi di wilayah tersebut. Salah satu infrastruktur telekomunikasi yang akan dibangun pada tahun ini, yaitu di Pulau Miangas, Sulawesi Utara yang merupakan pulau terpulau Indonesia yang berbatasan dengan Filipina. Di pulau tersebut, pemerintah akan membangun infrastruktur telekomunikasi seperti pembangunan base transceiver station (BTS). Sejauh ini Kementerian Komunikasi dan Informatika (Kominfo) telah membangun ratusan BTS di wilayahwilayah perbatasan dan terluar. Sebagai contoh, di sejumlah wilayah perbatasan di Pulau Kalimantan telah terbangun sekitar 77 BTS untuk mengakomodir para operator telekomunikasi untuk memperluas jaringannya ke wilayah tersebut (http://bisnis.liputan6.com/read/30200 72/pemerintah-bangun-infrastrukturtelekomunikasi-di-pulau-miangas dipulish tanggal 12 Juli 2017, diakses pada tanggal 15 September 2017).

\section{Pembelajaran/Media Literasi}

Kedekatan geografis daerahdaerah perbatasan menyebabkan 
tingginya interaksi antara masyarakat di daerah tersebut dengan masyarakat negara tetangga. Akses yang mudah dan cepat serta kesamaan budaya memberikan kemudahan interaksi yang dalam. Kondisi ini di lain hal memberikan nilai positif dalam kehidupan sehari-hari, mulai dari pemenuhan kebutuhan mencari pekerjaan, maupun kebutuhan seharihari. Namun, dalam jangka panjang cenderung memberikan dampak negatif terhadap rasa cinta tanah air. Selain tentunya akan mereduksi peranan masyarakat terhadap pembelaan negara di wilayah perbatasan.

Bela negara merupakan suatu tekad, sikap, dan tindakan warga negara yang teratur, menyeluruh, terpadu, dan berlanjut dengan dilandasi kecintaan terhadap tanah air Indonesia. Bela negara wajib dilakukan oleh setiap warga negara disertai adanya kesadaran berbangsa dan bertanah air. Kesadaran bela negara pada dasarnya merupakan kesediaan warga negara Indonesia untuk mau berbakti dan berkorban pada negara (Tuhana Taufiq Andrianto, 2015: 28).

Untuk mengatasi masalah ini, hal yang bisa dilakukan adalah pemberian wawasan kebangsaan dan penegasan status kependudukan, serta peningkatan kualitas SDM penduduk daerah-daerah perbatasan. Di samping itu, pembangunan infrastruktur menjadi bukti negara hadir memenuhi kebutuhan hajat hidup masyarakat di wilayah perbatasan. Ketahanan daerah perbatasan menjadi kewajiban negara untuk terwujudnya kedaulatan negara. Jika kondisi yang dihadapi saat ini membawa perubahan besar bagi kehidupan masyarakat Indonesia di perbatasan, maka negara hadir dengan memberikan lebih banyak lagi kontribusi positif bagi kehidupan mereka. Seperti dalam isu pemenuhan kebutuhan informasi, pembelajaran informasi, infrastruktur informasi dan pembangunannya sebagai pedoman penting dan pertimbangan utama dalam pertahanan negara. Begitu pula dalam hal kesejahteraan umum, pembangunan di wilayah perbatasan 
hendaknya dipandang dari aspek ekonomi berkelanjutan. Aspek ekonomi ini sangat penting agar disparitas wilayah perbatasan dengan negara tetangga tidak terlalu tinggi.

Pemahaman mengenai media literacy tidak lagi berangkat dari semata upaya proteksi, tetapi lebih kepada sebuah pemberdayaan (empowerment). Media tidak dilihat dari satu sisi yang penuh potensi negatif, melainkan lebih kepada upaya memaksimalkan sisi positif yang dapat diperoleh dari media (pemberdayaan). Media literacy atau melek media menurut Rachmiatie adalah suatu istilah yang digunakan sebagai jawaban atas maraknya pandangan masyarakat tentang pengaruh dan dampak yang timbul akibat isi (content) media yang cenderung negatif dan tidak diharapkan. Khalayak perlu diberi kemampuan, pengetahuan, kesadaran, dan ketrampilan secara khusus (Darwadi MS, 2017: 41). Silverblatt (Ibid) menyatakan bahwa seseorang dikatakan memiliki keterampilan literasi media apabila dirinya memuat faktor-faktor sebagai berikut:

1. Sebuah kesadaran akan dampak media terhadap individu dan masyarakat.

2. Sebuah pemahaman akan proses komunikasi massa.

3. Pengembangan strategi-strategi yang digunakan untuk menganalisis dan membahas pesan-pesan media.

4. Sebuah kesadaran akan isi media sebagai 'teks' yang memberikan wawasan dan pengetahuan ke dalam budaya kontemporer manusia dan diri manusia sendiri.

5. Peningkatan kesenangan, pemahaman, dan apresiasi terhadap isi media.

Minimnya siaran nasional di daerah perbatasan sudah menjadi isu lama dan segera dilakukan perubahan. Konsep yang paling pas meredam semua masalah penyiaran adalah dengan memberikan sebanyakbanyaknya siaran dari dalam negeri, baik itu siaran lokal maupun nasional. Namun, untuk mewujudkan itu, kita 
harus menyelesaikan hal-hal dasar, seperti penyediaan infrastruktur guna menarik investor untuk mendirikan lembaga penyiaran di perbatasan. Ketersediaan infrastruktur juga akan mempermudah pendirian lembaga penyiaran publik (LPP) RRI dan TVRI khusus perbatasan dan LPP lokal oleh pemerintah daerah, baik itu pemerintah kota maupun kabupaten. Aspek lain yang penting ditindaklanjuti adalah bagaimana membangun masyarakat di wilayah tersebut, antara lain dengan memberikan pembelajaran atau media literasi. Masyarakat di perbatasan harus bisa mengkontrol dan memilah tayangan mana yang baik dan tepat. Ini juga berkaitan dengan pengembangan program gerakan cinta siaran Indonesia dalam rangka meningkatkan nasionalisme di kawasan perbatasan antar negara.

Selain itu, peran media massa juga sangat penting di daerah perbatasan. Sebagai salah satu sumber informasi penghubung, kontrol sosial terhadap kebijakan sekaligus mempromosikan nilai-nilai yang bersifat nasional antara masyarakat perbatasan dan negara. Namun, sumber daya manusia yang mengelola media massa juga belum memadai sehingga berdampak pada kemampuan jurnalistik para awak media serta prospek perkembangannya dalam konteks bisnis komersil. Begitu pula dengan segmentasi masyarakat yang kritis sehingga dapat mengawasi objektifitas media massa selain potensi sikap partisan media massa (https://news.detik.com/kolom/258104 5/media-massa-di-daerah-konflik-danperbatasan diakses pada tanggal 1 Desember 2017).

\section{Kesimpulan}

Kondisi bangsa Indonesia dihadapkan pada kemajuan informasi dan teknologi yang mengharuskan masyarakat untuk menyikapi dengan baik dan bertanggungjawab. Di sisi lain, daerah-daerah perbatasan Indonesia malah dihadapkan pada kurangnya informasi terhadap perkembangan negara sendiri. Selama ini pandangan bahwa ketahanan nasional berkisar pada ketahanan 
politik, ekonomi, pangan dan lainnya, namun ketahanan informasi tidak kalah penting dalam mewujudkan ketahanan nasional bangsa. Kebutuhan informasi dan kesadaran atas informasi yang berkembang memberikan kontribusi terhadap ketahanan bangsa menghadapi ancaman yang dapat datang dari mana saja di negara ini.

Begitu pentingnya ketahanan informasi sehingga menjadi isu penting dalam mewujudkan ketahanan nasional di era teknologi saat ini, ditambah dengan daerah perbatasan yang rentan dengan ketimpangan menjadi bukti bahwa pemerataan semua sektor kehidupan harus dimulai dari yang mulai terabaikan yaitu informasi. Selama ini perhatian negara terhadap daerah-daerah perbatasan hampir seluruhnya terfokus terhadap pertahanan dan keamanan negara, namun meninggalkan aspek yang tidak kalah penting yaitu penguatan modal sosial yaitu kebutuhan informasi.

$$
\text { Pengembangan teknologi }
$$

informasi di daerah perbatasan sangat erat kaitannya dengan masalah kedaulatan bangsa dan negara, kesejahteraan masyarakat, pelayanan publik kepada masyarakat perbatasan yang masih tertinggal dan kurang terurus, serta keberlanjutan lingkungan hidup yang tercukupi. Berbagai isu tentang minimnya informasi di daerah perbatasan telah diinventarisasi dan diidentifikasi permasalahannya dalam rangka perumusan kebijakan nasional pengelolaan perbatasan negara yang bertujuan untuk mewujudkan kawasan perbatasan sebagai beranda depan negara. Usaha tersebut antara lain pengembangan infrastruktur dan mempermudah proses perizinan bagi perusahaan media informasi dan peningkatan pembelajaran/media literasi kepada masyarakat di daerah perbatasan. Tinggal menunggu perkembangan dan perubahan di daerah perbatasan yang sama-sama dapat dirasakan masyarakat sehingga ketahanan nasional dapat terwujud dan membuat Indonesia semakin cakap dan kuat menghadapi permasalahan yang akan muncul dari dalam dan luar negeri. 


\section{Daftar Kepustakaan}

Burhan Bungin. (2007). Penelitian Kualitatif: Komunikasi, Ekonomi, Kebijaka Publik, Dan Ilmu Sosial Lainnya. Edisi pertama. Cetakan ke-2. Jakarta: Kencana.

Darmadi Hamid. (2013). Urgensi Pendidikan Pancasila dan Kewarganegaraan di Perguruan Tinggi. Bandung: Alfabeta.

Darwadi MS. Media Baru Sebagai Informasi Budaya Global. Jurnal Komunikator 9, no 1 (2017).

Informasi Beberapa Daerah di Riau Berkiblat ke Malaysia, Jumat, 18 Agustus 2017. Dalam http://harianriau.co/news/detail/1 4978/informasi-beberapa-daerahdi-riau-berkiblat-ke-malaysia diakses pada tanggal 15 September 2017.

Informasi Beberapa Daerah di Riau Berkiblat ke Malaysia. Dalam http://harianriau.co/news/detail/1 4978/informasi-beberapa-daerahdi-riau-berkiblat-ke-malaysia terbit tanggal 18 Agustus 2017 diakses pada tanggal 15 September 2017.

KPID: Mahal Menyaksikan Siaran di Wilayah Perbatasan. Dalam http://www.daririau.com/read9008790--kpid-mahalmenyaksikan-siaran-di-wilayahperbatasan.html diterbitkan tanggal 17 Desember 2013 diakses pada tanggal 15 September 20017.

Media Massa di daerah Konflik dan Perbatasan. Dalam https://news.detik.com/kolom/25 81045/media-massa-di-daerahkonflik-dan-perbatasan diakses pada tanggal 1 Desember 20017.

Membangun Ketahanan Informasi Menegakkan Ketahanan Nasional. Dalam https://tniad.mil.id/2017/01/mem bangun-ketahanan-informasimenegakkan-ketahanan-nasional/ diterbitkan tanggal 13 Januari 2017 diakses pada tanggal 15 Sepetember 2017.

Pemerintah Bangun Infrastruktur Telekomunikasi di Pulau Miangas. Dalam http://bisnis.liputan6.com/read/3 020072/pemerintah-banguninfrastruktur-telekomunikasi-dipulau-miangas dipulish tanggal 12 Juli 2017, diakses pada tanggal 15 September 2017. 
Pendirian lembaga penyiaran di perbatasan dipermudah. Dalam http://kanalsatu.com/id/post/157 8/pendirian-lembaga-penyiarandi-perbatasan-dipermudah diterbitkan tanggal, 2 April 2013, diakses pada tanggal 13 September 2017.

Teknologi Minim di Daerah Perbatasan. Dalam http://lipi.go.id/berita/teknologiminim-di-daerah-perbatasan/ $\underline{1224}$ diakses pada tanggal 16 Septeber 2017.

Tuhana Taufiq Andrianto. (2015). Paradigma Baru Bela Negara Implemetasi dan Pengembangannya di Era Globalisasi. Yogyakarta: Global Pustaka Utama.
WNI jadi WN Malaysia karena kesenjangan infrastruktur di daerah perbatasan. Dalam http://www.dpd.go.id/artikelwni-jadi-wn-malaysia-karenakesenjangan-infrastruktur-diperbatasan diterbitkan tanggal 8 Juni 2010, diakses pada tanggal 15 September 2017.

www.kemitraan.com Partnership Policy Paper No.2/2011. Kebijakan Pengelolaan kawasan Perbatasan Indonesia.

Zainuddin Djafar. "Masyarakat Perbatasan RI-Malaysia dan Kasus Askar Wataniah: Relevansi Perubahan Kebijakan Kesejahteraan". Jurnal masyarakat \& Budaya 10, no. 1 (2008). 